\title{
Czy pokój nieodparcie zapanuje w świecie? Co, zgodnie z traktatem Kanta Ku wieczystemu pokojowi, gwarantuje nam natura?
}

Odnośnie do przyszłych dziejów ludzkości Kant prezentuje czasami trochę osobliwe stanowisko, ponieważ: czy chcemy, czy nie, na pokój jesteśmy skazani; natura prowadzi ludzi i narody ku stanowi, w którym wojna nie będzie mogła być żadną opcją polityczną. Świat w całości globus terraqueus oplecze związek praw, które połączą republiki, te zaś ze swej strony nie będą więcej zainteresowane prowadzeniem wojen i z tego powodu zaczną dobrowolnie przestrzegać normy, jakie same na siebie nałożyły. Taka wizja znakomicie wyłożona jest we wstępie do Definitywnych artykułów w rozprawie Kanta o Wiecznym pokoju; rozprawa nosi tytuł O gwarancji wiecznego pokoju (AA VIII, 360 i n.) $)^{1}$.

\footnotetext{
${ }^{1}$ Rozprawa w moim przekładzie ukazała się w Toruniu w roku 1996 pod tytułem Do wiecznego pokoju. W najbliższych miesiącach ukaże się ona w redagowanym przez nas VI tomie Dzieł zebranych Kanta pod tytułem Ku wieczystemu pokojowi. Tę zgrabniejszą propozycję tłumaczenia tytułu zaproponował nieodżałowanej pamięci Jan Garewicz. W obu wypadkach chodzi oczywiście o to samo dzieło, odnośniki zaś do stron w oryginalnym wydaniu Akademie Ausgabe zamieszczone są tam na marginesie (przyp. M. Żelazny).
} 
Tuż przed początkiem fragmentu będącego przedmiotem naszego zainteresowania Kant twierdzi, że w nowych czasach prawo kosmopolityczne stanie się elementem dopełniającym prawa narodów i prawo państwowe, a to z powodu, że ludzkość w swym całokształcie osiągnie status wielkiej wspólnoty: bezprawie dokonujące się w jakimś miejscu, powiada, odczuwane będzie wszędzie. Stan wiecznego pokoju, o ile ma być osiągnięty, wymaga więc obok prawa narodów czegoś takiego jak jawne prawo człowieka, które obok tego pierwszego dotyczyć będzie innych praw. O problemie tym dyskutowali już wcześniej inni autorzy. Ale Kant, naturalnie w sensie czysto retorycznym zapytuje sam siebie i swego czytelnika: co może dać nam pewność, że taki stan pokoju mógłby zostać któregoś dnia osiągnięty? Przy pobieżnej lekturze odpowiedź zdaje się brzmieć: nie ma naturalnego prawa, co znaczy, że natura sama rozwiąże wątpliwe sytuacje, niezależnie od tego, co się będzie działo.

Kant argumentuje krótko, po pierwsze: zgódźmy się w ogóle, że naturę można rozpatrywać tak, jak gdyby dążyła do określonego celu. Po drugie, że wolno nam przyjąć, iż będzie to właśnie ten cel, który człowiekowi wyznaczył praktyczny rozum: pokój między ludźmi. Po trzecie, że jeśli naturę rozpatrywać będziemy w taki sposób, możemy odkryć, jak - czyli „w jaki sposób” natura ów będący przedmiotem pytania cel realizuje. Wszystko to ostatecznie wykaże, że natura gwarantuje, iż ów cel zostanie również osiągnięty. Tu przytoczymy w krótkiej formie odpowiednie cytaty:

Gdy mówię o naturze, że chce, aby zaszło to, lub tamto, nie znaczy to, że nakłada ona na nas obowiązek, by tak właśnie czynić (co może zrobić tylko wolny od przymusu praktyczny rozum), lecz że czyni ona sama, niezależnie, czy my tego chcemy, czy też nie (fata volentem ducunt, noletnem trahunt) ${ }^{2}$.

W tym miejscu można powiedzieć: przyroda chce bezwzględnie, by prawo dysponowało ostatecznie wyższą władzą. To, czego zaniedbano tu uczynić, zrealizuje się koniec końcem samo, chociaż z większymi trudnościami³.

Powyższe fragmenty skłaniają początkowo do założenia, że Kant chciał nas przekonać, iż natura stan wiecznego pokoju osiągnie faktycznie, niezależnie od tego, co się może wydarzyć. Jeśli ludzkość sama z siebie nie wydo-

\footnotetext{
${ }^{2}$ I. Kant, Ku wieczystemu pokojowi (365,28 n.).

${ }^{3}$ Tamże (367,3 nn.).
} 
będzie stanu pokoju, zostanie ona do niego zmuszona, na zasadzie: nolentem trahunt, co znaczy, „kto nie chce, ten zostanie przymuszony”.

Zanim argumenty Kanta rozpatrzymy po kolei, wyjaśnijmy dwa zasadnicze problemy takiego punktu widzenia.

Pierwszym jest problem epistemologicznego punktu widzenia: czy rzeczywiście wiemy, że natura stworzy stan pokoju, nawet jeśli nie stworzy go sama ludzkość? Czy argumenty Kanta rzeczywiście na to wskazują?

Drugie ma sens praktyczny („praktyczny” naturalnie w filozoficznym sensie tego słowa): jeśli będący przedmiotem pytania sposób widzenia zawiera w podanym praktycznym kontekście jakiekolwiek odniesienia, to natura winna zrealizować swe zadanie $\mathrm{w}$ dającym się przewidzieć czasie, a nie dopiero w dalszej perspektywie, tzn. gdy wszyscy będziemy martwi; musi więc istnieć jakieś jej odniesienie do naszych uczynków, bo w innym wypadku trudno byłoby określić, co Kantowskie przesłanie z pisma o „wiecznym pokoju" miałoby w praktycznym aspekcie w ogóle oznaczać. Innymi słowy: czym byłaby w ogóle praktyczna przemyślność gwarancji natury, jeśli nie odnosiłaby się ona w jakikolwiek sposób do przewidywalnej przyszłości? Jednakże, jeśli natura i tak spełni swe zadania w przewidywalnej przeszłości, to wówczas obowiązek osiągnięcia stanu wiecznego pokoju staje się dla ludzi pusty. Nikt nie jest przecież zobligowany do tego, ażeby spełniać coś, co natura tak czy inaczej urzeczywistni w nadchodzącym czasie. Gdyby nam powiedziano, że zobowiązani jesteśmy troszczyć się o to, by wieczorem było ciemno, nie wyznaczałoby to naturalnie żadnych ograniczeń wolności naszego postępowania, bo przecież zupełnie nie wiedzielibyśmy, co powinniśmy czynić, a czego nie, by zrealizować swój domniemany obowiązek. Nie ma tu żadnego przymusu, żadnej konieczności, jak również żadnego imperatywu, a zatem a fortiori żadnego obowiązku. Taki stosunek rzeczy jest po prostu uzupełnieniem znanej figury ultra posse nemo obligatur.

Co się tyczy pierwszego punktu, epistemologicznego, to odnoszący się do niego argument odnajduje Kant w założeniu teleologicznym: tym, dotyczącym celowości natury. Będący przedmiotem pytania cel nie może być ani rozpoznany bezpośrednio, ani nie da się go wyprowadzić za pomocą określonych, uznanych za prawdziwe założeń, gdyż w obydwu wypadkach nie mamy do czynienia ze sposobem, w jaki cele mogłyby zostać przypisane jakiemukolwiek fenomenowi. Jak powiada sam Kant, celem jest tu coś, co musimy sobie dopowiedzieć. Ale jak tu wyprowadzić dopowiedzenie, że natura rzeczywiście sama z siebie osiągnąć chce stan pokoju? Celowość maszynki do kawy nie gwarantuje nam przecież, że rano będziemy mieli kawę, więcej, nie czyni 
tego nawet prawdopodobnym. Po to, ażeby celowość miała cokolwiek wspólnego z rzeczywistym osiągnięciem celu, musi wydarzyć się coś dodatkowego.

Jeśli jednak gwarancja nie może gwarantować, że pokój nadejdzie sam przez się, to co w takim razie gwarantuje, co „czyni” natura, jeśli nie osiąga ona stanu wiecznego pokoju - niezależnie od tego, co by się nie wydarzyło?

\section{II}

Przyjrzyjmy się fragmentowi, który zawiera się bezpośrednio przed przytoczonymi powyżej obydwu cytatami. Otrzymamy wówczas pewną wskazówkę:

Teraz wyłania się pytanie dotyczące istoty wiecznego pokoju jako zamierzenia: „co robi przyroda dla realizacji owego zamierzenia, czy też celu, który dla człowieka uczynił obowiązkiem jego własny rozum, a zatem dla wsparcia jego zamierzeń moralnych, i w jaki sposób zagwarantuje ona, że człowiek pod jej przymusem, jednak bez szkody dla własnej wolności, czyniłby we wszystkich trzech dziedzinach publicznego prawa: państw, narodów i prawa kosmopolitycznego to, do czego zobowiązują go prawa wolności, ale czego jednak nie czyni? ${ }^{4}$

„Wsparcie moralnego zamierzenia człowieka jest dziełem natury”, natura zaś zapewnia następnie to, że ludzkość rzeczywiście czyni coś, co zgodnie z prawami natury czynić powinna. Przejdźmy do następnego punktu: możemy go interpretować na dwa sposoby. Po pierwsze, jako zgodność ze wzmiankowanym przeświadczeniem, że natura bezwzględnie zmusza ludzi, by czynili to, co czynić powinni. Po drugie, możemy to jednak odczytać jako zapewnienie, że wszystko, co ludzie czynią i co nie pozostaje w zgodności $\mathrm{z}$ prawami wolności, natura ustawicznie rozbija. Innymi słowy: jak długo ludzie postępują w sposób fałszywy, tak długo będzie ona niszczyć ich dzieło. Nie oznacza to niczego innego jak założenie, że nie ma w ludzkiej historii żadnej głównej ulicy, która w końcu nie okazałaby się uliczką, tzn. która, gdy chodzi o drogę w stronę ostatecznego celu ludzkości, jakim jest wieczny pokój, nie okazałaby się ślepa. Natura drzwi do wiecznego pokoju pozostawia zawsze otwarte, ale przekroczenie ich jest zadaniem człowieka i nie na

\footnotetext{
${ }^{4}$ Tamże (365,20 nn.).
} 
miejscu są tu wszelkie usprawiedliwienia w rodzaju formuły ultra posse nemo obligatur: natura gwarantuje, że ludzkie wznoszenie się ku wyższemu politycznemu celowi zawsze jest rozumne i nigdy nie stanie się chimeryczne. Taki jest adekwatny sposób odczytywania formuły przytoczonego cytatu: natura „wspiera moralne zamierzenie” człowieka, pozostawiając otwarte drzwi do wiecznego pokoju.

Ale jest jeszcze inny sens tej gwarancji, polegający mianowicie na tym, że natura człowieka dysponuje wszelkimi środkami, jakie tylko są mu potrzebne, by do owego celu dążyć. $Z$ jednej strony drzwi pozostają zatem otwarte, z drugiej zaś zostaną dostarczone środki umożliwiające przejście przez nie. Takie są faktycznie obydwa sposoby postrzegania owej gwarancji, którą Kant w swej rozprawie określa mianem gwarancji naturalnej. Wyjaśnię to następująco.

Pod koniec pierwszego dodatku do definitywnych artykułów Kant dokonuje podsumowania:

W ten sposób, poprzez sam mechanizm ludzkich skłonności gwarantuje przyroda wieczny pokój; naturalnie z pewnością, która nie jest dostateczna, by (teoretycznie) przepowiedzieć czas jego nadejścia, która jednakże praktycznie jest osiągalna i obliguje nas, ażeby dążyć do tego (bynajmniej nie chimerycznego) celu ${ }^{5}$.

Praktyczna gwarancja, jak możemy odczytać z tego fragmentu, nie jest niczym innym aniżeli gwarancją skuteczności. Sama w sobie nie ma żadnego potencjału prognozującego, bo będące przedmiotem pytania relacje mogą zaistnieć między rzeczami w ogóle tylko wtedy, gdy ktoś faktycznie podąża ku określonym celom. Wieczny pokój nie wyniknie z samego tylko działania natury - to żadna podstawa do gwarancji. Ale ludzkie wznoszenie się w kierunku wiecznego pokoju nigdy nie będzie daremne, tzn. nie stanie się polowaniem na chimerę, gdyż natura gwarantuje, że warunki, które umożliwiają tu skuteczność, zawsze pozostają w ludzkim zasięgu. Ta gwarancja zapewnia, iż o ile człowiek dąży ku celowi wiecznego pokoju, może ufać, że skuteczność - przynajmniej w zasadzie zawsze jest możliwa, bo owe polityczne konstelacje i sytuacje, w ramach których skuteczność staje się płonna, nigdy nie są trwałe. Naturalna gwarancja, jako „praktyczna” gwarancja wiecznego pokoju, nigdy nie jest tylko prawdopodobieństwem (coś takiego oznaczałoby

\footnotetext{
${ }^{5}$ Tamże $(368,15$ nn.).
} 
pojmowanie całej sprawy z pozycji teoretycznych rozważań historycznych). Prawdopodobieństwo osiągnięcia wiecznego pokoju jest prawdopodobieństwem wyłącznie w tym sensie, że ludzie mogą się ku temu celowi kierować, albowiem dokładnie tak (by jeszcze raz przytoczyć powyższy przykład, jak ma to miejsce z prawdopodobieństwem, że rano będziemy mieli kawę, która zależy nie tylko od celowości maszynki do kawy, lecz od prawdopodobieństwa wszystkich rzeczy dotyczących natury (tak jak w przytoczonej analogii maszynki) kogoś, kto się ową maszynką posługuje. Jednakże bez celowości i solidności gwarancji prawdopodobieństwo osiągnięcia celu (porannej kawy) oraz ostatecznego stanu historii też nie będzie zależało od inicjatywy postępowania. W efekcie będąca przedmiotem pytania gwarancja, jako gwarancja praktyczna, jest koniecznym, lecz w żadnym wypadku niewystarczającym warunkiem skuteczności.

\section{III}

Kant przedstawia trzy scenariusze dotyczące negatywnego aspektu gwarancji natury, tzn. scenariusz zamknięcia ulicy głównej lub bocznej uliczki, co blokuje drogę ku wiecznemu pokojowi. W niniejszym rozdziale skoncentruję się na tym aspekcie. Pozytywny sens gwarancji, bycie otwartym na środki odpowiednie do zaistnienia pokoju, stanie się tematem następnego, czwartego rozdziału. W tym względzie Kant dostrzega trzy wielkie przeszkody, które mogą utrudnić osiągnięcie przez człowieka przypisanego mu moralnie celu, czyli celu świata, w którym ludzkie postępowanie uregulowane jest przez zasady prawne.

Pierwsza możliwa przeszkoda polegałaby na tym, że ludzie, jako indywidua, albo jako rodziny są od siebie trwale odizolowani i $z$ tego powodu nie mogą wejść w uregulowane prawem związki. Drugą byłoby powstanie wielkich wspólnot politycznych, co prowadziłoby do duchowego despotyzmu. Trzecia sprowadzałaby się zaś do tego, że zaistniałaby mnogość małych wspólnot politycznych, a niedobór wzajemnych związków wiecznie doprowadzałby je do stanu wojny. W sposób oczywisty te trzy „stadia uliczek” ludzkiego rozwoju odpowiadałyby trzem rodzajom prawa: prawu państwowemu, prawu narodu i prawu kosmopolitycznemu.

Natura, jeśli rozważamy ją jako Opatrzność, rozwinęła odpowiednio do tego trzy środki zaradcze przeciwdziałające temu, by takie beznadziejne sytuacje nie mogły zapanować na stałe: po pierwsze, tendencję do wojny, po 
drugie, różnicę języków i religii, po trzecie, ducha handlu. Przejdźmy do punktu pierwszego, czyli tendencji do wojny:

1. Jeśli nawet wewnętrzne waśnie nie zmuszą narodu, ażeby podporządkował się przymusowi powszechnych praw, wojna uczyni to od zewnątrz, dlatego że zgodnie z wyżej zaprezentowanym prawem przyrody każdy naród odnajduje w swym sąsiedztwie naciskający na niego inny naród, przeciw któremu jest wewnętrznie zmuszony zorganizować się w państwo, ażeby jako siła być zdolnym do oporu'.

Tutaj Kant wyprowadza skłonność do tego, by ludzie rozproszyli się po powierzchni całej Ziemi z samej natury. Uczyniła to ona w ten sposób, że skumulowała środki do życia we wszystkich miejscach, z drugiej strony zaś pozwoliła separować się od siebie, zaszczepiając w nich tendencję do wojny. W efekcie skłonność do wojny - pisze Kant, została zaszczepiona w ludzką naturę jako cel sam w sobie. Można go więc uznać za środek natury stymulujący nas do zasiedlenia wszelkich połaci Ziemi na całym świecie. Idźmy dalej: skłonność do wojny zmusza lokalne związki rodzinne do tworzenia trwałych porządków prawnych, bo tylko w ten sposób jedni mogą skutecznie bronić się przed drugimi.

Po drugie, by wesprzeć „tendencję do izolowania się sąsiednich państw: ażeby zapobiec uniwersalnemu despotyzmowi (i w ten sposób zdławienie sił republikańskich)", natura wymyśliła dwa środki, które powinny zapobiec wymieszaniu różnorodnych ludów: zróżnicowanie języka i zróżnicowanie religii. W wyniku obu tych czynników skłonność państw, by swe terytorium i swą populację rozszerzać w nieskończoność, zostaje poważnie ograniczona. Zamiast osłabienia wszelkich sił przez reżim jakiejś uniwersalnej monarchii dochodzi raczej do żywotnego sporu narodów, ten zaś doprowadza do prosperującej wielkości państw. Państwa te, jeśli są republikami, mogą dobrowolnie połączyć się w większą całość i to dokładnie wówczas, kiedy tego chcą (tego uczy nas drugi artykuł definitywny).

Po trzecie, „duch handlu”: ponieważ podczas izolacji narodów i pociągu ku wojnie ledwie można dążyć do pragnącej spokoju wspólnoty, jako trzeci moment gwarancji wprowadziła dodatkowo natura ducha handlu. Gdy takowy panuje, państwa będą próbowały za pośrednictwem powiązań handlowych zapobiec wojnom dokładnie tak, jak gdyby realizując ów cel, łączyły się

\footnotetext{
${ }^{6}$ Tamże (365,33 nn.).
} 
w trwały związek państw. To zaś wspiera chwalebny pokój bez konieczności stosowania pobudek moralnych. Jeżeli te trzy elementy rozważymy we wzajemnym związku, to chronią one ludzkość w trojaki sposób przed popadnięciem w błąd. Pojedyncze państwa będą powstawać we wszelkich dających się pomyśleć miejscach i we wszystkich czasach, dążąc do stabilnej wspólnoty. Żadne z nich nie pójdzie tak daleko, by ukonstytuować stały i uniwersalny despotyzm, a rozliczne pojedyncze państwa, dzięki wzajemnym stosunkom handlowym ze swej strony, nie będą mogły pozostawać na stałe w stanie wojny. Tym sposobem natura w rzeczywistości chroni ludzkość przed wejściem w jedną z tych trzech ślepych uliczek. Po pierwsze, przed tym, żeby na stałe nie zapanowała anarchia, bez politycznego i prawnego kształtu. Po drugie, przed wszechświatowym despotyzmem, który osłabia ludzkie siły, przede wszystkim zaś siły prawa. Po trzecie wreszcie, przed permanentną wojną między licznymi państwami. W żadnym z tych trzech przypadków nie chodzi jeszcze o wieczny pokój.

\section{IV}

Stwierdziłem powyżej, że istnieje trzeci aspekt naturalnej gwarancji, który Kant komunikuje swojemu czytelnikowi w piśmie O wiecznym pokoju. Natura gwarantuje mianowicie skuteczność ludzkiego wznoszenia się ku wiecznemu pokojowi, gdy dodatkowo daje ludzkości do ręki odpowiednie środki do utrzymania adekwatnych opinii na temat postępowania. Temu aspektowi poświęcony jest znany „fragment o diabłach”.

Problem zorganizowania państwa jest rozwiązywalny, mówiąc bez ogródek, nawet dla narodu diabłów (jeśli tylko posiadają one rozum) i wyrażałby się następująco: w taki sposób zorganizować pewną liczbę istot rozumnych, które dla swego przetrwania wspólnie potrzebują powszechnych praw, z których jednak każda w tajemnicy skłonna jest uchylać się od nich i tak zorganizować ich ustrój, ażeby, bez względu na przeciwieństwa ich prywatnych pobudek, te ostatnie na tyle były przez nich nawzajem powstrzymywane, że w publicznych stosunkach między nimi rezultat byłby taki, jak gdyby owych złych pobudek nie mieli oni w ogóle ${ }^{7}$.

7 Tamże (366,15 nn.). 
$\mathrm{O}$ co tu chodzi? Fragment znajduje się w rozdziale, który wiąże się z pierwszą z wymienionych powyżej ślepych uliczek: natura poprzez skłonność do wojny skłania pojedyncze narody do podporządkowania się prawom państwowym, przeciwdziałając w ten sposób temu, by ludzkość nie pozostawała w stanie pozbawionej prawa anarchii. W tym miejscu Kant urządza krótką wycieczkę, która poprzez domniemane pytania pośrednie motywowana jest w następujący sposób: „Jeśli natura podporządkowuje człowieka przymusowi powszechnego prawa, to czy daje mu także do ręki środek, ażeby tego rodzaju porządek osiągnąć i potem uczynić stabilnym? Albo czy taki porządek nie byłby w ogóle możliwy tylko w państwie bogów lub aniołów, które nie wykazują silnych skłonności samolubnych znanych nam ludziom?". Pytanie to zostało postawione $\mathrm{w}$ rzeczywistości przez Rehberga $\mathrm{w}$ jednej $\mathrm{z}$ recenzji pisma Kanta O porzekadle: to może być słuszne w teorii, ale nic nie jest warte w praktyce. I właśnie w piśmie o Wiecznym pokoju Kant wykorzystuje możliwość, by na zarzut Rehberga odpowiedzieć: „ten problem byłby rozwiązywalny nie tylko dla bogów czy aniołów, pisze, lecz nawet dla diabłów" go jest on realnie rozwiązywalny dla istot ludzkich. Nie istnieje zatem żadne usprawiedliwienie dla tych książąt i królów, którzy swego własnego reżimu z samolubnych powodów nie chcą przemieniać w republikę, bo republika jest ostatecznie jedyną stabilną formą rządzenia o charakterze prawnomoralnym.

Dlaczego zatem pytać, czy problem jest rozwiązywalny? Dlatego że natura żąda „mechanizmu, skłonności”, który może zostać użyty przez sprawujących rządy i prawodawców:

[...] przy pomocy tych właśnie egoistycznych skłonności i tylko od dobrej organizacji państwa (która w każdym wypadku pozostaje w mocy człowieka) zależy, czy siły owych skłonności zostaną w taki sposób skorygowane, ażeby

\footnotetext{
${ }^{8}$ To, że Kant mówi tu o „diabłach” (a nie o, jak to się wcześniej wyraził w przytoczonym explicite kontekście, o obdarzonych intelektem istotach, które swe "prywatne skłonności” ustawicznie podporządkowują przyczynie moralnej, krótko: o „pragmatycznych zwierzętach” i wynika tylko z kontekstu polemicznego (Kanta Państwo diabłów, por. Rousseau Państwo bogów, Contract Social III, 4). Diabły sensu stricto w ten sposób zostałyby przez swój „diabelski” rozum tak pociągnięte do zła jak „święte istoty” przez praktyczny rozum do dobra, mianowicie niezależnie od pobudzania ich przez skłonności (por. Ugruntowanie metafizyki moralności, AA IV 414, gdy idzie o świętych, a Religię w obrębie samego rozumu AA VI, 35, gdy chodzi o istoty diabelskie; gdy idzie o przeciwstawienie: Metafizyczne podstawy nauki o cnocie AA VI 461). Prawdopodobnie „diabelskie istoty” byłyby dlatego pobudzane w równie niewielkim stopniu przez mechanizm skłonności do zła jak „święte istoty” przez skłonność do dobra.
} 
jedna z nich albo powstrzymywała niszczycielskie zapędy innej, albo unicestwiała je?.

Naturalnie problem jest rozwiązywalny tylko dla ludu „diabłów”, a nie przez naród diabłów dla samych siebie, bo żaden (Kantowski) diabeł nie uczyniłby użytku z mechanizmu natury w taki sposób, że sam przez się wspierałby on jakiś moralny cel jak np. organizację republikańskiego rządu. Takie diabelskie państwo przymusu nie pomoże ostatecznie żadnej republice diabłów przetrwać.

Jednakże prawny mechanizm natury, wprowadzony w prawidłowy sposób do dzieła, wiedzie Kantowskie diabły do celu: jeśli w jakimś dobrze zorganizowanym ustroju koszty wspierania czysto prywatnych (albo wręcz złych) skłonności są wystarczające, to również Kantowscy „diabelscy” obywatele spróbują prowadzić swe życie w zgodności ze skłonnościami odpowiadającymi prawu. Ma to miejsce tam, gdzie mechanizmowi natury możemy podporządkować swoje działania. Jeśli wszystko będzie celowe, pojawi się troska, ażeby prywatne interesy nawzajem między sobą neutralizować i ostatecznie podjąć działania, które zewnętrznie tak oddziałują, jakby były działaniami obywateli republiki aniołów.

\section{V}

Na początku przyczynku do rozdziału o gwarancjach Kant przytacza krótki przegląd, w którym ustala perspektywę troskliwej aktywności natury. Prowizoryczna organizacja natury

[...] polega na tym, że: 1) zatroszczyła się o to, by ludzie mieli możliwość życia we wszystkich regionach Ziemi; - 2) poprzez wojny rozsiała ludzi nawet do najbardziej niedogodnych dla gospodarki okolic, aby one również były zasiedlone; - 3) poprzez wojnę przymusiła ludzi, aby wstępowali w mniej lub bardziej prawne stosunki ${ }^{10}$.

„W mniej lub bardziej prawnych stosunkach konieczne jest” - co też natura „czyni”, nie to, by wydobyć stosunki ujęte w ustawie, czyli konsty-

\footnotetext{
${ }^{9} \mathrm{Ku}$ wieczystemu pokojowi (366,11 nn.).

${ }^{10}$ Tamże (363,3 nn.).
} 
tucję republikańską. Takowa stwarza tylko warunki, w których ludzie, jako prawodawcy i rządzący, mogą zrobić użytek z mechanizmów natury i zatroszczyć się o to, by normalni ludzie zewnętrznie zachowywali się jak prawdziwi republikanie, jak ludzkie istoty dążące do celu, jakim jest wieczny pokój.

Wizerunek natury jako Opatrzności polega więc na tym:

to idea, przesadna wprawdzie $\mathrm{w}$ odniesieniu teoretycznym, ale w odniesieniu praktycznym (na przykład przy rozpatrywaniu wynikającego z obowiązku pojęcia wiecznego pokoju i wykorzystania w tym celu mechanizmu natury) stanowi ona dogmat $\mathrm{i}$ jej realność jest w pełni uzasadniona ${ }^{11}$.

Gwarancja naturalna nie jest tu gwarancją rezultatu, który Opatrzność może sprawić, lub przewidzieć, lecz tylko gwarancją efektu, który jest obiecywany: o ile mechanizm natury używany jest przez ludzi w adekwatny sposób, może to przyczynić się do postępu, gdy idzie o wprowadzenie wiecznego pokoju.

Oba komponenty gwarancji sytuują się następująco: natura prowadzi człowieka na stopień, gdzie otrzymuje on do dyspozycji środki, dzięki którym jego moralne obowiązki mogą być spełnione w sposób oczywisty. Jeśli tak będziemy postrzegać naukę Kanta, to z pewnością okaże się ona nie tak idiosynkratyczna, jak można byłoby to początkowo przypuszczać na podstawie przedstawionej interpretacji.

Chciałbym dla ilustracji zaprezentować trzy możliwe scenerie światowej wspólnoty, będącej nie wspólnotą typu anielskiego, lecz wspólnotą racjonalnych istot, przejawiających takie skłonności, które z reguły przeszkadzają czynić rzeczy nakazane moralnie.

1. Możemy przyjąć, że współgranie ludzkich skłonności i naturalnej sytuacji ludzkości (przynajmniej w dłuższej perspektywie) udaremnią człowiekowi skuteczne postępowanie $\mathrm{w}$ harmonii $\mathrm{z}$ nakazanymi moralnie celami: każda próba stworzenia republiki, albo osiągnięcia „wiecznego pokoju” z powodu ludzkiego egoizmu, po krótkotrwałych na początku efektach, skończy się ostatecznie w jakiejś ślepej uliczce (uniwersalna anarchia, uniwersalny despotyzm, absolutna separacja narodów itp.).

2. Z drugiej strony natura mogłaby też być w pełni neutralna, w tym sensie, że nakazany cel republikanizacji osiągnięto by tylko wówczas, gdyby

${ }^{11}$ Tamże (362,8 nn.). 
„moralna rewolucja” zaszłaby w każdej pojedynczej ludzkiej istocie. Skuteczny stan republikański albo „wiecznego pokoju” nastałby wówczas, ale tylko wówczas, gdyby wszyscy stali się moralnymi herosami (aniołami lub bogami), którzy skutecznie odrzucą swe prywatne skłonności.

3. Natura wspiera moralne dobro, gdy osiągnie taki poziom, na którym pojedyncze osoby podejmujące działania czują się wyposażone w owe środki, następnie zaszczepią je w państwie, kierując postęp ludzkości w stronę moralnego celu. Cel ten nie może zostać osiągnięty, niezależnie od ludzkich dążeń, ale natura przynajmniej gwarantuje, że wysiłki pojedynczych ludzi nie będą daremne nawet wtedy, gdy inni nie podzielają ich celów.

Myślę, że Kant chciałby nam tu przybliżyć fakt, że byłoby czymś bezsensownym, nieodpowiednim, a nawet praktycznie zakazanym, traktować naturę tak, jak gdyby była ona naturą trzeciego typu. Bo właśnie prowadzi ona człowieka do stanu, w którym jedyny błąd mógłby polegać na tym, że ludzkość nie wyszłaby ze stanu wiecznej wojny (tak jak było to nie do uniknięcia w pierwszym i drugim scenariuszu, gdzie cum grano salis można byłoby stosować jako warianty Augustiańskie scenariusze civitas terrena), jednostkowi, co najmniej jednak określeni, dający się zidentyfikować pojedynczy ludzie ponoszą odpowiedzialność za bieg świata.

\section{VI}

Kim jest więc ten, kto mechanizm natury ma urzeczywistnić w działaniu. Wiemy już z poprzednich fragmentów tekstu, kto tego nie czyni, ale zdaniem Kanta bezwzględnie czynić powinien: są to mianowicie regenci anciens regimens, którzy powodują, że staje się niemożliwe wprowadzenie republikańskiej konstytucji, gdyż ta jest rzekomo przywilejem aniołów, a nie prostych ludzi jako obywateli. Ale kto jest motorem republikańskiego ustroju? Tu pozytywna odpowiedź Kanta jest również jasna. W jednym z późniejszych fragmentów zostaje to tak określone:

Każdy sposób sprawowania rządów (z wyjątkiem autentycznie republikańskiego, który jednak może istnieć tylko w wyobraźni moralnego polityka) posiada w historii przykład swego przeciwieństwa ${ }^{12}$.

${ }^{12}$ Tamże (377,29 nn.). 
Prawdziwa republika nadejdzie, a kimś, kto przygotuje jej nadejście, jest moralny polityk, którego Kant opisuje w powyższym fragmencie i który postępuje zgodnie z wymaganiami naturalnych gwarancji.

Nie chciałbym tu wnikać w szczegóły, ale tylko przypomnieć o niektórych z przytoczonych cytatów, dających nam pewność, że sam Kant nie myślał o tym, iż natura nie może doprowadzić do wiecznego pokoju bez swych moralnych agentów, to znaczy bez ludzi, którzy formalne zasady rozumu czynią swymi osobistymi politycznymi maksymami. Znaczy to, że: bez ludzi, których sam on zwie politykami moralnymi,

[...] maksymy polityczne muszą być ustanawiane nie ze względu na oczekiwany w wyniku ich stosowania dobrobyt i szczęście każdego pojedynczego państwa, zatem nie ze względu na cel, który każde [z tych państw] stawia przed sobą (na wolę), jako wyższą (lecz empiryczną) zasadę mądrości państwowej, lecz ze względu na czyste pojęcie obowiązku prawnego (na powinność, której zasada dana jest a priori przez czysty rozum) bez względu na to, jakie fizyczne skutki miałyby z tego wyniknąćc

Oczywiście, powiada Kant, polityk zakłada wolność, tzn. możliwość postępowania zgodnie z moralnym prawem.

Naturalnie, jeśli nie ma wolności i ugruntowanego na niej moralnego prawa, lecz wszystko, co dzieje się lub co dziać się może, jest po prostu mechanizmem przyrody, to polityka (jako sztuka używania tego mechanizmu do rządzenia ludźmi) stanowi całą praktyczną mądrość, zaś pojęcie prawa jest pustą myślą ${ }^{14}$.

Sam tylko mechanizm natury nie doprowadzi do pokoju, gdyż nie byłoby wówczas żadnych zadań, których realizacja wymaga politycznych aktorów, a których niezawodność mogłaby je zabezpieczyć. Zdaniem Kanta tacy politycy, którzy swych politycznych maksym nie wyjaśniają poprzez odwołanie do prawa moralnego, tzw. politycznych moralistów, należy krytykować za to, że nie traktują oni prawa moralnego jako podstawy polityki.

\footnotetext{
13 Tamże (379,11 nn.).

14 Tamże (372,1 nn.).
} 
Oponujący przeciw temu moraliści polityczni mogą sobie, ile im się podoba, mędrkować nad naturalnym mechanizmem, któremu podlegają ludzkie masy zawiązujące się w społeczeństwo, a który czyni owe podstawowe zasady bezsilnymi [...]. Nie zasługują oni na posłuch przede wszystkim dlatego, że ich zgubna teoria sama przyczynia się do zła, które przepowiada. Zgodnie z tą teorią człowiek zaliczony zostaje do tej samej klasy, co żywe maszyny, którym brak jedynie świadomości, iż nie są wolnymi istotami, ażeby we własnej opinii stać się najbardziej nieszczęsnymi istotami na świecie ${ }^{15}$.

Na koniec, jeśli raz jeszcze przejrzymy partie wstępne, gdzie Kant pisze o szyldzie owego karczmarza, który nazwał swą gospodę „Pod wiecznym pokojem"16, widzimy, dlaczego filozof w ogóle napisał tę rozprawę i jakim celom służył fragment o gwarancji natury: adresatami są tu mianowicie wszyscy ludzie - i ci, którzy angażują się w politykę, którzy proponują albo wyznaczają polityczne zasady w Prusach i Europie - ci, których Kant zwie praktycznymi politykami. To posłanie ma podwójny sens: najpierw Kant powiada im, jakie są ich prawdziwe obowiązki - wyraża to w Artykułach definitywnych, stosujących się do władzy państwowej - a dalej powiada, że z ich strony nie może wyjść żadna wymówka, która nie byłaby z tymi artykułami zgodna: z rozdziału o Gwarancji naturalnej mogą się politycy nauczyć, że jeśli tylko zgodzą się z tymi tezami, mogą stać się skuteczni - więcej, że prawdopodobnie nawet sami już o tym wiedzą.

Polityk, takie jest polityczne przesłanie Wiecznego pokoju, podporządkowuje się prawu stanowionemu, które nie jest niczym innym aniżeli obowiązującą nauką prawa; a jeżeli nie wyniknie z tego moralny cel, czyli pokój między ludźmi, wówczas każdy może ponosić za to odpowiedzialność: dotyczy to zwłaszcza politycznych moralistów, którzy w imię dobrobytu i domniemanej korzyści obywateli podporządkowują prawo rzekomej politycznej moralności. Trwało to tylko pięć lat i już Kant mógł uznać, iż otrzymał do ręki dowód, że prawo moralne stało się w Europie relewantnym politycznym

\footnotetext{
15 Tamże (378, $22 \mathrm{nn}$.$) .$

${ }^{16}$ Niemiecki termin Zum ewigen Frieden ma dwa znaczenia. Karczma, na której szyldzie zamieszczono to hasło, była po prostu karczmą o nazwie „Pod wiecznym pokojem”, tak jak („Zum Hirsch” oznacza karczmę „pod jeleniem”). Dosłownie zaś zum ewigen Frieden znaczy: „Ku wieczystemu pokojowi”. Karczmarz wykorzystał tę dwuznaczność. Na szyldzie karczmy napisał: „Pod wiecznym pokojem” znaczące równocześnie „Ku wieczystemu pokojowi”, a na tablicy szyldu namalował cmentarz. Postawił więc retoryczne pytanie: czy wieczysty pokój możemy osiągnąć dopiero na cmentarzu, jak to obiecuje nam duchowny na pogrzebie? AA VI, 275, 4 (przyp. M. Żelazny).
} 
faktorem. Uczestnicy francuskiej rewolucji, tak powiada Kant w Sporze fakultetów, okazali przez swój entuzjazm, że ludzie dali zapowiedź o gotowości wkroczenia na polityczną scenę jako moralni politycy. Koniec końców dowodzi to, zdaniem Kanta, nie tylko faktu, że praktyczny rozum w ogóle jest, ale również tego, że praktyczny rozum może stać się polityczny. Nawet jeśli dziś ów optymizm całkowicie nas opuścił, obydwie podstawowe idee Kantowskiej „naturalnej gwarancji” pozostają nieodpartymi założeniami każdej odpowiedzialnej polityki. Z jednej strony będą to przekonania, że ani globalna anarchia, ani despotyczna hegemonia jakiejś pojedynczej mocy, ani polityczna fragmentaryzacja świata nie mogą stworzyć trwałego i stałego, ostatecznego stanu historii. $Z$ drugiej zaś strony pogląd, że wypracowanie zabezpieczonej prawem wolności zależeć będzie od tego, czy polityczni aktorzy wykształcą w sobie wolę, by stworzyć takie instytucje, w których prawidłowym obywatelem jest obywatel rozumny - bez potrzeby uczynienia go wcześniej aniołem.

Przełożył Mirosław Żelazny

\begin{abstract}
Will Peace Invincibly Prevail in the World? What Does Nature Assure Us of, According to Kant's Treatise Perpetual Peace?

In his "Eternal Peace", Kant introduces a "natural guarantee" of perpetual peace. On first sight, this guarantee seems to relieve humans from the obligation to promote eternal peace acitively, because it will develop anyway. But Kants calls this "guarantee" a practical one, that is, a mere guarantee of success: Human conduct aiming art the attainment of Peace will not be in vain. Hence this guarantee prevents political leaders in Europe from escaping their responsibility by claiming that perpetual peace would only be possible in a world of holy beings, but not with humans.
\end{abstract}

